\title{
Pensando en espiral
}

Por: Leonardo Comba

Docente MT, programa de Diseño Gráfico

Areandina, sede Bogotá.

El territorio ancestral del cual provenimos cuenta con maravillosas muestras de lo que conocemos como arte rupestre, grabados y pinturas hechos sobre superficies rocosas en épocas que se saben remotas, aunque en su mayoría no puedan ser datadas con precisión, realizadas por antiguos habitantes de lo que hoy llamamos Colombia. En el centro del país, en los departamentos de Cundinamarca y Boyacá principalmente, permanece la cultura indígena que encontraron los invasores europeos a su llegada en el siglo XVI, los Mhuysqas. A pesar de todo, la cultura Mhuysqa no está extinta, como se cree generalmente, y cada vez surgen más individuos y colectivos que se reconocen pertenecientes a esta etnia.

Actualmente son cinco las comunidades reconocidas legalmente por el estado como pertenecientes a la cultura Mhuysqa, en las localidades de Bosa y Suba en Bogotá, y en las poblaciones de Cota, Chía y Sesquilé en el departamento de Cundinamarca. Según datos del Censo Nacional de Población realizado por el Dane en el año 2005, de 14.051 indígenas 
Mhuysqas registrados, 5.713 residen Bogotá, 2.410 en Cota, en Chía 1.843 y en otros contextos urbanos se encuentran 10.243 personas (Ministerio del Interior, S.F., p.1). Según este censo, en Boyacá se contabilizaron 212 Mhuysqas en Tunja y 223 en Sogamoso.

Como parte de las actividades de investigación del proyecto Simbología visual ancestral en las comunidades Muiscas contemporáneas, desarrollado en el año 2016, se visitaron algunas comunidades de esta cultura, como es el caso del Cabildo Mhuysqa de Suamox, ubicado en la ciudad de Sogamoso. Esta comunidad hace parte de un número creciente de colectivos que, aunque no están reconocidos legalmente, se auto-reconocen como Mhuysqas.

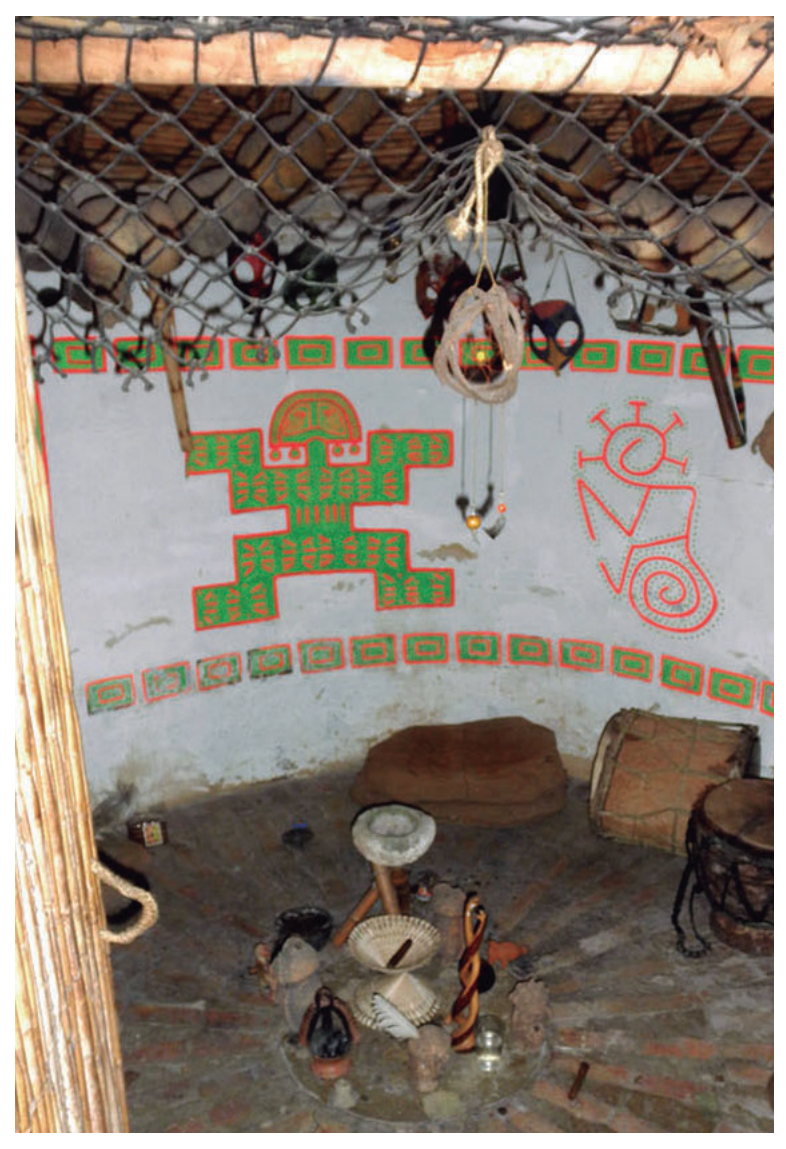

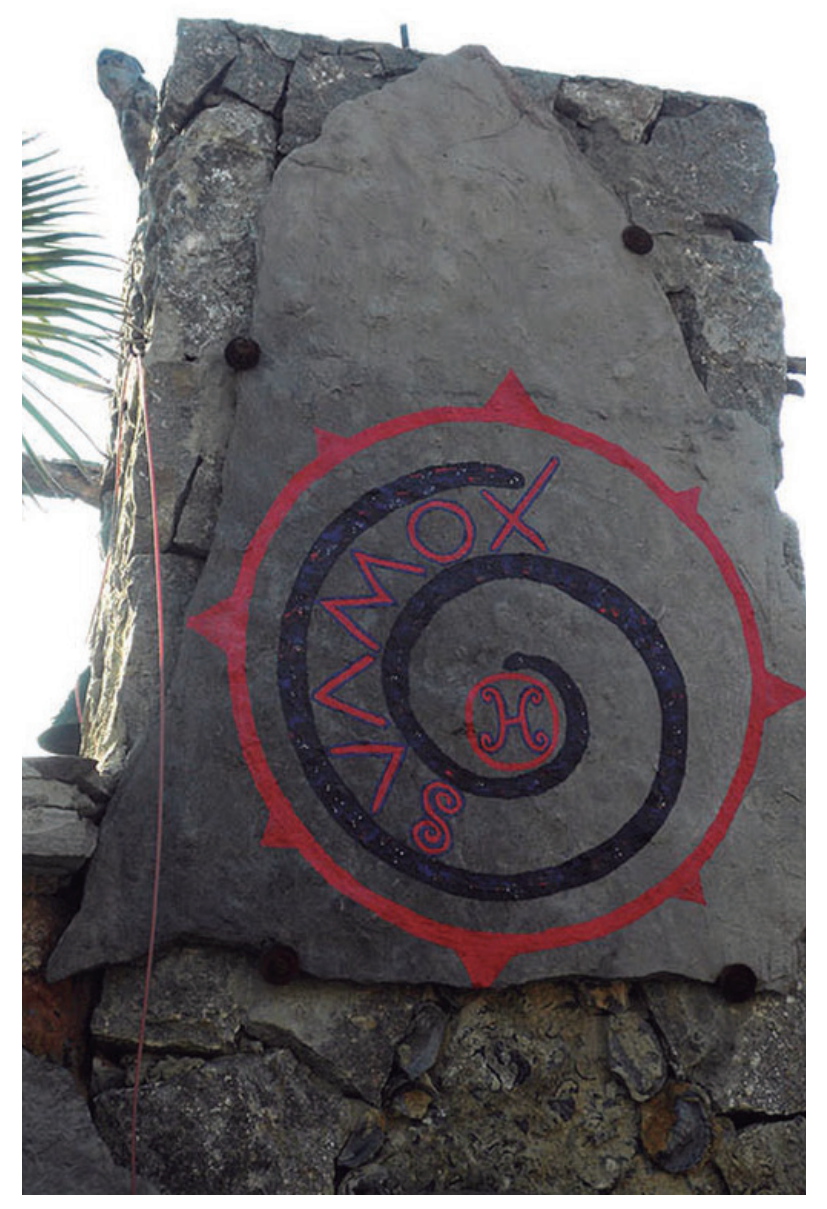

Partiendo de la inquietud sobre las maneras en que estas nuevas comunidades se relacionan con los signos visuales prehispánicos del altiplano cundiboyacense, y tomando como método base la etnometodología, se recopiló información sobre algunos de los símbolos visuales ancestrales integrados a las dinámicas que adelantan con el fin de reconstruir su identidad cultural. A pesar de que no se pueden afirmar fechas, significados originales, ni autoría de las imágenes ancestrales consignadas en la roca y en la palabra de esta región, se les relaciona con los Mhuysqas históricos. De acuerdo a este vínculo, los Mhuysqas contemporáneos continúan su legado apropiando y resignificando estos símbolos. 
